\title{
A Characterization of Inflammatory and Structural Markers within the Rumen Epithelium During Grain-Induced Ruminal Acidosis in Lactating Dairy Cattle
}

\author{
${ }^{1}$ Dionissopoulos, L., ${ }^{1}$ M.A. Steele, ${ }^{1}$ O. AlZahal, ${ }^{2}$ J.C. Plaizier and ${ }^{1,2}$ B.W. McBride \\ ${ }^{1}$ Department of Animal and Poultry Science, \\ Ontario Agricultural College, University of Guelph, Guelph, ON N1G 2W1, Canada \\ ${ }^{2}$ Department of Animal Science, University of Manitoba, Winnipeg, MN R3T 2N2, Canada
}

Received 2012-06-13, Revised 2012-07-10; Accepted 2012-08-18

\begin{abstract}
The objective of this study was to characterize the mRNA and protein expression of inflammatory and structural genes in the rumen epithelium during grain-induced ruminal acidosis in lactating dairy cattle. A total of 16 rumen-fistulated, lactating Holstein dairy cattle ( $618 \pm 35 \mathrm{~kg}$ of body weight, $221 \pm 32$ days in milk) were used in a randomized complete block design study. All cattle were initially fed a high-forage diet (HF; $88.9 \%$ of dry matter) and after a baseline (wk 0 ) measurement, half of the cattle were randomly assigned and transitioned to a high-concentrate diet (HC; $62.2 \%$ of dry matter) which was fed for 3 weeks (weeks 1 , 2 and 3). Continuous ruminal $\mathrm{pH}$, ruminal LPS and plasma LPS-binding protein were measured each week followed by a rumen papillae biopsy used for mRNA and protein quantification. After the baseline period, ruminal LPS was higher in HC compared to HF cattle (28851 \pm 6905 vs. $\left.5771 \pm 3042 \mathrm{EU} \mathrm{mL}^{-1}\right)$. There was no difference in mRNA expression of inflammatory and structure genes in rumen papillae between HF and HC cattle during all weeks. With regard to protein expression, there was an up regulation $(p=0.02)$ of nuclear factor of activated T-cells cytoplasmic 2 expression during weeks 1,2 and 3; however, all other inflammatory markers within the rumen epithelium were unchanged by treatment. These results suggest that although graininduced ruminal acidosis leads to characteristic whole-animal inflammatory response, only marginal changes in inflammatory and structural gene and protein expression in the rumen epithelium were detected.
\end{abstract}

Keywords: Rumen Epithelium, Ruminal Acidosis, Inflammation, Gene Expression

\section{INTRODUCTION}

To meet the demands of milk production in early lactation, it has become common to feed dairy cattle diets rich in rapidly fermentable carbohydrates. When cattle are fed rapidly fermentable diets, typically achieved by high inclusion levels of grains, the rate of ruminal acid production may exceed the rate of ruminal absorption and buffering, causing a digestive disorder termed ruminal acidosis. The sub acute form of ruminal acidosis, termed SARA, has become common in North American dairy production systems and is typically diagnosed when ruminal $\mathrm{pH}$ drops below 5.6 for more than three hours per day (AlZahal et al., 2007). Sub acute ruminal acidosis has been shown to depresssruminal fiber digestion, feed intake, milk production and milk fat and has become a significant economic issue in our dairy industry (Plaizier et al., 2008).

Dairy cattle health and welfare can be compromised by grain-induced SARA as it has been associated with rumenitis, bloat, liver abscesses and laminitis (Plaizier et al., 2008). A more recent finding is that grain-induced SARA causes an increase in the concentration of acute phase proteins such as Serum Amyloid A (SAA) and Haptoglobin (Hp) in peripheral blood, indicative of systemic inflammatory response (Gozho et al., 2007;

Corresponding Author: Dionissopoulos, L., Department of Animal and Poultry Science, Ontario Agrigultural College, University of Guelph, Guelph, ON N1G 2W1, Canada 
Plaizier et al., 2008). The whole-animal inflammatory response during grain-induced SARA is thought to be initiated through altered permeability of the gut, such as the Rumen Epithelium (RE) (Penner et al., 2011), which enables the transmigration of microbes and immunogenic compounds into portal circulation. The structural transformations and inflammation of the RE during graininduced SARA have been characterized (Steele et al., $2011 \mathrm{~b}$ ), but the precise molecular mechanisms triggering these events are unknown.

It has been known for some time that increases in grain intake lead to a large and sudden increase in ruminal gram negative bacterial load (Motoi et al., 1993). It has recently been shown that there is an increase in lysis of gram-negative bacteria, causing an increase in ruminal LPS during grain-induced ruminal acidosis, which may be triggering a localized inflammation of the RE (Gozho et al., 2007; Nagaraja and Titgemeyer, 2007). Consequently, increases in acidity, coupled with LPS, may work together to damage the RE, thereby initiating a local inflammatory response that will eventually lead to antigen clearance, wound healing and the reestablishment of homeostasis (Thibault et al., 2010). Currently it is not known whether changes in RE integrity are the result of immune-mediated events corresponding to changes in gene and protein expression. A review of the literature reveals that one of the most ubiquitous and important transcription factors controlling the expression of pro-inflammatory cytokine and chemokine genes is Nuclear Factor $\kappa \mathrm{B}(\mathrm{NF}-\kappa \mathrm{B})$ (Hoffmann and Baltimore, 2006; Calder, 2008). It has been extensively characterized that LPS interacts with Toll-Like Receptors (TLR), thereby activating mitogenactivated protein kinases and subsequently nuclear NF$\kappa \mathrm{B}$. It is possible that the elevation in ruminal LPS could be triggering an immune response during grain-induced SARA; therefore, an examination of expression patterns of cytokines and chemokines involved in this immunomodulatorycascade is warranted.

Recent efforts investigating the molecular adaptation of the RE during SARA in dairy cattle have focused on characterizing the expression profiles of metabolic and transporter genes at the mRNA level (Penner et al., 2009; 2011; Steele et al., 2011b; 2012). There is a scarcity of information regarding the expression of key inflammatory pathways at both the mRNA and protein levels. By studying inflammatory pathways, we can better understand the biochemical and perhaps the genetic factors that lead to disease. Therefore, the aim of this study is to characterize the mRNA and protein expression of key inflammatory and structural gene targets during grain- induced SARA. We hypothesized that the grain-induced ruminal acidosis in lactating dairy cattle is associated with the differential mRNA and protein expression of inflammatory genes in the RE.

\section{MATERIALS AND METHODS}

\subsection{Animals, Experimental Treatments and Feeding}

The outline of the experimental design and treatments has been described previously by Steele et al. (2012). In brief, sixteen multiparous, rumen-cannulated, lactating Holstein dairy cattle $(618 \pm 35 \mathrm{~kg}$ of BW, $221 \pm 32$ DIM, mean \pm SD) housed in a tie-stall facility at the Ponsonby Dairy Research Station were used in this study (University of Guelph, Guelph, Ontario, Canada). All experimental procedures were approved by the University of Guelph Animal Care Committee in accordance with the Canadian Council on Animal Care (Olfert et al., 1993).

All cattle were gradually transitioned to a high-forage diet (HF; $88.9 \%$ hay, $6.7 \%$ grain pellet, $4.4 \%$ supplement $\%$ of DM; $16.2 \%$ CP, $46.9 \%$ NDF, $27.9 \%$ NFC, $7.4 \%$ starch) five wk preceding the experiment. The protein supplement and hay were fed at $0800 \mathrm{~h}$ and $1600 \mathrm{~h}$ in equal allotments and a grain mix (40\% ground wheat, $40 \%$ ground barley, $20 \%$ ground corn) was fed at 0800,1200 and $1600 \mathrm{~h}$, also in equal allotments. To maintain consistency of dietary intake between cattle, the concentrate portion was fed in plastic trays and all leftovers were introduced into the rumen via the fistula if animals did not consume it within 60 min post feeding. At the end of week 0 , the cattle were randomly assigned to be maintained on the control group (HF) diet or transitioned to an $\mathrm{HC}$ diet (HC; $37.8 \%$ hay, $57.8 \%$ grain pellet, $4.4 \%$ supplement $\%$ of DM; $14.5 \% \mathrm{CP}$, $32.3 \%$ NDF, $46.0 \%$ NFC, $27.9 \%$ starch). The transition to the $\mathrm{HC}$ diet was conducted in gradual increments over five days and $\mathrm{HC}$ cattle were fed the diet until the end of week 3.

\subsection{Physiological Measurements}

Physiological measurements were performed during the final two days of each week (weeks 0, 1, 2 and 3). For the last $48 \mathrm{~h}$ of each experimental week (weeks $0,1,2$ and 3), ruminal $\mathrm{pH}$ was recorded in the ventral sac as described previously by our research group (AlZahal et al., 2007). Ruminal fluid samples were collected at $1600 \mathrm{~h}$ for the last two days of each experimental week and assessed in duplicate for ruminal SCFA concentration by gas chromatography as previously described (Steele et al., 2012). Another portion of the rumen fluid sample was processed for determination of free LPS concentrations in $\mathrm{HC}$ cattle by a chromogenic Limulus Amoebocyte 
Lysate (LAL) end-point assay (QCL-1000, Lonza Group Ltd., Basel, Switzerland) as described by Gozho et al. (2005). To monitor blood LPS-Binding Protein (LBP) concentration, a 14-gauge catheter (Becton Dickinson Angiocath, Franklin, NJ) was inserted into one jugular vein of each cow under local anaesthesia in the morning before blood collection. Blood samples were collected at $800 \mathrm{~h}$ and $1600 \mathrm{~h}$ during the final day of each experimental week from $\mathrm{HF}$ and $\mathrm{HC}$ cattle. Immediately after collection, blood samples were put on ice, centrifuged at $3000 \mathrm{~g}$ for $15 \mathrm{~min}$ and frozen at $-20^{\circ} \mathrm{C}$ until analysis. The concentration of LBP in plasma was determined in duplicate using previously described methods (Gozho et al., 2005).

\subsection{Rumen Papillae Biopsies for mRNA and Protein Quantification}

Rumen papillae were biopsied from the ruminal ventral sac at the end of weeks 0, 1, 2 and $3(0700 \mathrm{~h})$ based upon previously developed methodology (Steele et al., 2011a; 2011b). In brief, the reticulo-rumen contents were partially evacuated to facilitate the retraction of the ventral sac. Rumen papillae were excised (150 mg) using surgical scissors each week from previously unbiopsied sites and washed 20 times in ice-cold PBS (pH 7.4) (Steele et al., 2011a; 2011b).

Rumen papillae were snap-frozen in liquid nitrogen, then stored at $-80^{\circ} \mathrm{C}$ until total RNA or protein could be isolated. The target genes to assess immune changes in the RE Included Interleukin-1 (IL1), Interleukin-1 ReceptorAssociated Kinase 1 (IRAK1), Nuclear Factor of Activated T-Cells Cytoplasmic 2 (NFATC2), Tumor Necrosis FactorAlpha (TNFA), Interleukin 6 (IL6) and Nuclear Factor Kappa B (NFKB), B-Cell Lymphoma/leukemia 10 (BCL10), and Inhibitor of nuclear factor Kappa-B Kinase subunit Alpha (IKKA). In addition, Collagen Alpha-1-IV chain (COL4A1), Fibronectin (FN1), Laminin subunit Beta1 (LAMB1) were assessed as markers for changes in rumen epithelial structure.

Total RNA was isolated as previously described by Steele et al. (2012) using an RNeasy midi kit (Qiagen, Missisauga, Ontario, Canada) and the concentration was determined using a NanoDrop (ND-1000, NanoDrop Technologies, Wilmington DE). RNA was then treated with DNase (Invitrogen, Burlington, Ontario, Canada) prior to assessing the quality using an Agilent 2100 Bioanalyzer (Agilent Technologies Inc., Palo Alto, CA) and the RNA 6000 Nano kit (Caliper Life Sciences, Mountain View, CA). After RNA isolation and quality assessment, samples (5 $\mu \mathrm{g}$ each) were reverse-transcribed before iTaq SYBR Green (Bio-Rad Laboratories) qPCR analysis in duplicate using an ABI Prism 7000 (Applied Biosystems). The sequences, $\mathrm{R}^{2}$, standard curve slope and primer efficiencies of primers are presented in Table 1. Exon-spanning primers for target genes were designed using NCBI/Primer BLAST Primer Express (http://www.ncbi.nlm.nih.gov/tools/primerblast/) and bovine sequences listed in Gen Bank (National Center for Biotechnology Information, Bethesda, MD). The amp icons of all primers designed for this study were verified using BLASTN in NCBI and dissociation curves were generated at the end of amplification to verify the presence of a single product. On the basis of previous experimental protocols (Steele et al., 2011a), GAPD was determined to be the most stable housekeeping gene in the rumen papillae and was therefore used in this study. For each week, the relative mRNA expression of genes was calculated using the inverse of qPCR efficiency raised to Delta Ct (Pfaffl et al., 2004). The HF cattle were pooled for each week to create a control value to which each $\mathrm{HC}$ sample was normalized for determination of relative mRNA expression, as previously described (Xue et al., 2010).

Total protein from rumen papillae samples was extracted by the addition of a lysis buffer (Ready Prep Protein Extraction Kit; Bio-Rad Laboratories) before homogenization and centrifugation at $13,000 \mathrm{~g}$ for $25 \mathrm{~min}$ at $4^{\circ} \mathrm{C}$. Protein concentrations were determined using the Bio-Rad Protein Assay Kit. Proteins were resolved using glycerol-based SDS-polyacrylamide gels (12\%) and transferred to polyvinylidene difluoride membranes (Millipore) and immunoblotting was carried out using the SNAP I.D. System vacuum (www.Millipore.com). All primary antibodies were obtained from Santa Cruz Biotechnology (www.scbt.com) (IL1, cat. \#sc-7884; IRAK1, cat. \#sc-7883; NFATC2, cat. \#sc-13034; TNFA, cat \#sc-1351; BCL10, cat. \#sc-5611; IKKA, cat. \#sc-7120; COL4A1, cat. \#sc-9301; FN1, cat. \#sc-6952; LAMB1, cat. \#sc-23410; PCNA, cat. \#sc-7907, IL6, cat. \#sc-1265, NFKB, cat. \#sc-1190). After incubation with the appropriate secondary antibodies, the complexes were detected using the enhanced chemiluminescence method (ECL Advance Western Blotting Detection Kit; GE/Amersham,), visualized using the ChemiGenius2 Bioimaging system (Syngene; Cambridge, United Kingdom) and quantified (Gene Tools software; PerkinElmer). Equal loading was confirmed using alpha tubulin as a control (cat. \#sc-31782).

\subsection{Statistical Analysis}

Data was generated weekly using methods previously described (Steele et al., 2012). The data analysis for this study was generated using [SAS/STAT] software, Version 9.1 of the SAS System for Windows. Copyright (C) 2002-2003, SAS Institute Inc:

$$
\mathrm{Y}_{\mathrm{ijk}}=\mu+\mathrm{D}_{\mathrm{i}}+\mathrm{T}_{\mathrm{j}}+(\mathrm{D} \times \mathrm{T})_{\mathrm{ij}}+\mathrm{B}_{\mathrm{k}}+\varepsilon_{\mathrm{ijk}}
$$

Where:

$\mathrm{Y}_{\mathrm{ijk}} \quad=$ The dependent variable 
$\mu \quad=$ The overall mean

$\mathrm{D}_{\mathrm{i}} \quad=$ The fixed effect of $\operatorname{diet}(\mathrm{i}=1,2)$

$\mathrm{T}_{\mathrm{j}} \quad=$ The fixed effect of time or week $(\mathrm{j}=1, . ., 4)$

$(\mathrm{D} \times \mathrm{T})_{\mathrm{ij}}=$ The effect of the interaction of diet by time (ij $=1, . ., 8)$

$\mathrm{B}_{\mathrm{k}} \quad=$ The fixed effect of block or phase $(\mathrm{k}=1,2)$

$\varepsilon_{\mathrm{ijk}} \quad=$ The random residual error
Diet, time and block were considered fixed effects and week of experiment was used as a repeated measurement with cow as the subject. Cow was subjected to covariance structures and the covariance structure that gave the smallest Bayesian information criterion was used. As described previously, the Helmert contrasts (week 0 vs. 123, week 1 vs. 23 and week 2 vs. 3) were used to evaluate significant changes due to treatment.

Table 1. Primers for quantitative real time PCR (qPCR)

\begin{tabular}{|c|c|c|c|c|c|}
\hline Gene symbol & Name & Genbank accession & Primer $\left(5^{\prime}-3^{\prime}\right)$ & $\begin{array}{l}\text { Amplicon } \\
\text { size (bp) }\end{array}$ & $\begin{array}{l}\text { Efficiency } \\
(\%)\end{array}$ \\
\hline BCL10 & B-cell CL/lymphoma 10 & NM_001078028.1 & $\begin{array}{l}\text { F-CAAAGGACTGGATACCCTGGTCGAA } \\
\text { R-GGCTCACAGCTGCTACATTTCAGTC }\end{array}$ & 92 & 89 \\
\hline COLAA1 & $\begin{array}{l}\text { Bost Taurus collagen type } \\
\text { IV, alpha } 1\end{array}$ & NM_NM_001166511.1 & $\begin{array}{l}\text { F-GAGTCCAGGGTTTCCAGGCGAC } \\
\text { R-CCCAACGGTCCCGTGCCAAT }\end{array}$ & 104 & 87 \\
\hline FN1 & Fibronectin 1 & NM_001163778.1 & $\begin{array}{l}\text { F-CCAGCACAGCCACTTCCGTG } \\
\text { R-GGGCGTCAGGTGCTGTGGTC }\end{array}$ & 78 & 93 \\
\hline IKKA/CHUK & $\begin{array}{l}\text { Conserved helix-loop- } \\
\text { helix ubiquitous kinase }\end{array}$ & NM_174021.2 & $\begin{array}{l}\text { F-GAATCTCTGGAACAGCGCGCAA } \\
\text { R-ACCATCTCCGTGCTGTCGCT }\end{array}$ & 120 & 94 \\
\hline IL1 & Interleukin 1, beta & NM_174093.1 & $\begin{array}{l}\text { F-TGAACCGAGAAGTGGTGTTCTGCAT } \\
\text { R-CAGCTGCAGGGTGGGCGTAT }\end{array}$ & 145 & 87 \\
\hline IRAK1 & $\begin{array}{l}\text { Interleukin-1 receptor- } \\
\text { associated kinase } 1\end{array}$ & NM_001040555.1 & $\begin{array}{l}\text { F-GTGGATCAACCGCAACGCCC } \\
\text { R-GGGAGGGTGCCAAGCAGTGA }\end{array}$ & 98 & 85 \\
\hline LAMB1 & Laminin, beta 1 & NM_001206519.1 & $\begin{array}{l}\text { F-ACGACATTTGCTCCAAACCGCC } \\
\text { R-AGCTGGACGGAATGTCTTGAAGGT }\end{array}$ & 89 & 91 \\
\hline TNFA & Tumor necrosis factor & NM_173966.2 & $\begin{array}{l}\text { F-CCCTCCATCAACAGCCCTCTGG } \\
\text { R-TGATGTCGGCTACAACGTGGGC }\end{array}$ & 135 & 91 \\
\hline NFATC2 & $\begin{array}{l}\text { Nuclear factor of } \\
\text { activated T-cells, } \\
\text { cytoplasmic, calcineurin- } \\
\text { dependent } 2 \text {, transcript } \\
\text { variant } 3\end{array}$ & XM_608872.3 & $\begin{array}{l}\text { F-ACGGCGGCCAGCAGATGATT } \\
\text { R-AGCATGTTAGGCTGGCTCTTGTCT }\end{array}$ & 110 & 98 \\
\hline GAPDH & $\begin{array}{l}\text { Glyceraldehyde-3- } \\
\text { Phosphate } \\
\text { dehydrogenase }\end{array}$ & NM_001034034.1 & $\begin{array}{l}\text { F-TGGAAAGGCCATCACCATCT } \\
\text { R-CCCACTTGATGTTGGCAG }\end{array}$ & 129 & 84 \\
\hline
\end{tabular}

The PROC MIXED of SAS was used to analyze the relative gene expression for $\mathrm{HC}$ cattle (generated relatively to HF cattle) with time (week) and block (phase) as fixed effects. The $\mathrm{HC}$ relative gene expression values different from 1 were determined using T-statistics.

\section{RESULTS}

\subsection{Physiological Measurements}

As reported in Steele et al. (2012), dramatic differences in ruminal $\mathrm{pH}$ were evident between $\mathrm{HC}$ and HF cattle during experimental weeks 1,2 and 3 . In summary, the mean and minimum daily ruminal $\mathrm{pH}$ was lower $(p<0.01)$ in HC cattle compared to the HF cattle during experimental weeks 1,2 and 3 . The daily minimal ruminal $\mathrm{pH}$ reached levels below $\mathrm{pH} 5.0$ for each experimental week in $\mathrm{HC}$ cattle, indicative of a severe state of SARA. Week 1 was marked by the largest change in ruminal $\mathrm{pH}(\mathrm{p}<0.01)$ as $\mathrm{HC}$ cattle displayed $760 \pm 71 \mathrm{~min} \mathrm{~d}^{-1}$ and $1139 \pm 57 \mathrm{~min} \mathrm{~d}^{-1}$ below 5.6 and 6.0, respectively. As expected, total SCFA concentration was greater $(\mathrm{p}<0.05)$ in HC compared with HF cattle during weeks 1, 2 and 3 (Steele et al., 2012).

With respect to ruminal and blood inflammatory markers, ruminal LPS significantly increased $(p<0.05)$ in concentration from week $0\left(4121 \pm 478 \mathrm{EU} \mathrm{mL}^{-1}\right)$ through weeks $1\left(20649 \pm 522 \mathrm{EU} \mathrm{mL}^{-1}\right), 2\left(21854 \pm 694 \mathrm{EU} \mathrm{mL}^{-1}\right)$ and $3\left(32310 \pm 728 \mathrm{EU} \mathrm{mL}^{-1}\right)$ in $\mathrm{HC}$ cattle. LBP was higher $(\mathrm{p}<0.05)$ in $\mathrm{HC}$ cattle compared to HF cattle in the morning sampling (15.4 vs. $11.1 \pm 1.1 \mu \mathrm{g} \mathrm{mL} \mathrm{mL}^{-1}$ ); however, there were no differences due to treatment detected during the $1600 \mathrm{~h}$ sampling.

\subsection{Gene Expression}

The mRNA and protein expression of the all genes is presented in Table 2 and 3, respectively. There was no differential expression of mRNA of target genes between $\mathrm{HF}$ and $\mathrm{HC}$ cattle at any time point of this experiment. In accordance, there were minimal changes in the expression of all but one target protein. The relative protein expression of NFATc 2 was upregulated $(p=0.02)$ by 2-fold in HC cattle compared to HF cattle. 


\section{DISCUSSION}

The aim of this study was to investigate how the $\mathrm{RE}$ responds to the onset of grain-inducedruminal acidosis by characterizing the expression of immuneregulatory and structural genes. A comprehensive description of the nutritional model used to induce SARA by HC feeding in this study has previously been described by Steele et al., (2012). The form of ruminal acidosis detected in this study $(760 \pm 71 \mathrm{~min}$ $\mathrm{d}^{-1}$ below ruminal $\mathrm{pH} 5.6$ in cattle fed $\mathrm{HC}$ diet) was severe compared to previous studies which have evaluated the effect of SARA on the RE and whole animal inflammation in the dairy cow (Gozho et al., 2005; 2006; 2007; Khafipour et al., 2009a; 2009b; Steele et al., 2011a; 2011b).

Table 2. Least square means of fold change of the expression of genes in rumen tissue from cattle fed the high-concentrate diet (HC) relative to cattle fed high-forage diet $(\mathrm{HF})$. All cows $(\mathrm{n}=16)$ received HF diet during wk 0 and then assigned either HC $(\mathrm{n}=8)$ or $\mathrm{HF}(\mathrm{n}=8)$ diet. Gene expression values for HF cattle were normalized to 1 within each week individually

\begin{tabular}{|c|c|c|c|c|c|c|c|c|}
\hline \multicolumn{5}{|c|}{ Gene expression fold change from $\mathrm{HC}$ relative to $\mathrm{HF}$} & \multirow[b]{2}{*}{ SE } & \multicolumn{3}{|c|}{$\mathrm{P}$ (Interaction) } \\
\hline Gene Immune & wk 0 & wk 1 & wk 2 & wk 3 & & 0 vs 123 & 1 vs 23 & 2 vs 3 \\
\hline IKKA & 0.96 & 0.74 & 0.82 & 0.90 & 0.10 & 0.27 & 0.34 & 0.61 \\
\hline ILI & 0.73 & 0.66 & 0.73 & 0.72 & 0.15 & 0.89 & 0.76 & 0.96 \\
\hline NFATc2 & 0.86 & 1.17 & 1.23 & 0.94 & 0.15 & 0.43 & 0.54 & 0.35 \\
\hline IRAK 1 & 0.89 & 0.90 & 1.02 & 1.07 & 0.14 & 0.35 & 0.24 & 0.71 \\
\hline TNFA & 0.85 & 1.27 & 1.38 & 0.82 & 0.22 & 0.55 & 0.73 & 0.43 \\
\hline BCL10 & 0.76 & 0.78 & 0.79 & 1.08 & 0.12 & 0.40 & 0.34 & 0.12 \\
\hline \multicolumn{9}{|l|}{ Structural } \\
\hline LAMB 1 & 0.86 & 1.17 & 1.23 & 0.94 & 0.15 & 0.19 & 0.68 & 0.21 \\
\hline COL4 & 1.06 & 0.92 & 0.91 & 1.05 & 0.14 & 0.50 & 0.67 & 0.42 \\
\hline FN1 & 0.85 & 0.74 & 0.82 & 0.90 & 0.11 & 0.83 & 0.39 & 0.65 \\
\hline
\end{tabular}

Table 3. Expression of proteins in rumen tissue from cattle fed the High-Concentrate diet (HC) relative to cattle fed High-Forage diet $(H F)$. All cows $(n=16)$ received HF diet during wk 0 and then assigned either $\mathrm{HC}(\mathrm{n}=8)$ or $\mathrm{HF}(\mathrm{n}=8)$ diet

\begin{tabular}{|c|c|c|c|c|c|c|c|c|c|c|c|c|}
\hline \multirow[b]{2}{*}{ Protein immune } & \multicolumn{4}{|c|}{ Control } & \multicolumn{4}{|c|}{ SARE } & \multirow[b]{2}{*}{$\mathrm{SE}$} & \multicolumn{3}{|c|}{$\mathrm{P}$ (Interaction) } \\
\hline & wk 0 & wk 1 & wk 2 & wk 3 & wk 0 & wk 1 & wk 2 & wk 3 & & 0 vs 123 & 1 vs 23 & 2 vs 3 \\
\hline$\overline{\mathrm{IKKA}}$ & 0.58 & 0.63 & 0.64 & 0.69 & 0.49 & 0.45 & 0.61 & 0.66 & 0.12 & 0.95 & 0.33 & 096 \\
\hline IL6 & 0.74 & 0.71 & 0.87 & 0.95 & 0.78 & 0.64 & 0.88 & 0.96 & 0.12 & 0.70 & 0.54 & 0.99 \\
\hline NFATc2 & 1.43 & 1.01 & 1.12 & 1.17 & 0.77 & 1.44 & 2.33 & 2.49 & 0.50 & 0.02 & 0.25 & 0.90 \\
\hline NFKB & 1.08 & 1.08 & 1.30 & 1.51 & 1.27 & 1.80 & 1.85 & 2.38 & 0.47 & 0.33 & 0.99 & 0.63 \\
\hline TNFA & 0.62 & 0.72 & 0.77 & 0.68 & 0.59 & 0.58 & 0.71 & 0.70 & 0.10 & 0.85 & 0.37 & 0.61 \\
\hline $\mathrm{Bcl} 10$ & 0.92 & 0.69 & 0.80 & 0.79 & 0.79 & 0.45 & 0.64 & 0.70 & 0.14 & 0.86 & 0.57 & 0.76 \\
\hline Structural & & & & & & & & & & & & \\
\hline LAMB 1 & 1.04 & 1.17 & 1.84 & 1.65 & 1.10 & 1.02 & 1.36 & 1.33 & 1.30 & 0.30 & 0.51 & 0.70 \\
\hline COL4 & 1.80 & 1.69 & 1.99 & 1.95 & 1.62 & 1.20 & 1.88 & 1.17 & 0.32 & 0.44 & 0.93 & 0.16 \\
\hline FN1 & 1.08 & 0.88 & 1.13 & 1.10 & 0.69 & 0.65 & 0.75 & 1.09 & 0.20 & 0.38 & 0.88 & 0.15 \\
\hline Tub & 2.47 & 2.55 & 2.29 & 1.97 & 2.39 & 2.92 & 2.57 & 2.66 & 0.41 & 0.27 & 0.82 & 0.48 \\
\hline
\end{tabular}

It has been well established that gram-negative bacteria thrive in a carbohydrate rich environment. Therefore, a concerted overgrowth of ruminal gram-negative bacteria which shed LPS from their cell walls causes a rise in ruminal LPS. It can be speculated that a buildup of ruminal LPS can react locally on the RE or transmigrate through the RE, thus causing systemic inflammation (Khafipour et al., 2009b). The ruminal LPS in HC cattle was six times greater during weeks 1, 2 and 3 compared to the baseline week $\left(25310 \pm 478 \mathrm{EU} \mathrm{mL}^{-1}\right.$ vs. $\left.4121 \pm 478 \mathrm{EU} \mathrm{mL}^{-1}\right)$. However, the concentration of ruminal LPS in acidotic cattle reported in our study was lower than several studies. For example, Khafipour et al., (2009a; 2009b) and Li et al. (2012) reported ruminal LPS concentrations higher than 100,000 $\mathrm{EU} \mathrm{mL} \mathrm{m}^{-1}$ in spite of it being a more moderate form of
SARA. Several factors may play a role in this discrepancy, such as time of sampling, total feed intake, rumen volume and physiological state of the dairy cow. Nevertheless, the ruminal acidosis reported in this study was associated with an accumulation of ruminal LPS that may modulate an immune response locally in the RE or enter portal circulation and exert its effects systemically.

Free LPS is delivered from its place of origin to antigen presenting cells such as macrophages by the soluble acute phase protein LBP (Muta and Takeshige, 2001). As such, LBP is partially responsible for the initiation of the immune response following the gramnegative bacterial overgrowth in the rumen. Since LBP levels are elevated by large circulating amounts of LPS, it is conceivable that following a SARA challenge, LBP levels 
may indeed increase(Chen et al., 2003; Gozho et al., 2007). In our model, this is what accompanied changes in rumen LPS, which is in agreement with similar experimental models in dairy cattle that report elevated LBP (Khafipour et al., 2009b; Zebeli and Ametaj, 2009) and other acute phase proteins such as SAA and HP (Kleen et al., 2003; Plaizier et al., 2008).

With regard to the RE, it has been widely established that increasing dietary rapidly fermentable carbohydrate alters RE proliferation (Goodlad, 1978), gene expression (Steele et al., 2011b) and structure (Steele et al., 2011a). It is becoming increasingly clearer that each response has different causes, time courses to ultimately impact RE function. To examine the responsiveness of the RE during a grain-induced SARA in this study, the relative expression value of mRNA and protein of key targets involved in immune-regulatory and structural repair pathways were determined. This study marks the first time that these immune-modulatory genes have been shown to be expressed in the RE. However, based on our results, there were minimal changes in the expression of genes involved in innate immunity and epithelial re-modeling.

We can propose that adaptation to a high grain challenge proceeds through minimal activation of a local immune response in the RE. The only marker which showed an upregulation of protein expression due to the HC diet was NFATC2. This growth factor is widely expressed in digestive tissues (Wang et al., 2011) and belongs to a family of proteins responsible for the activation of T-cells (Maitra et al., 2009). Ultimately responding to modulation of the calcium/calcineurin signaling network, NFATC2 is normally found in a phosphorylated and inactive form in the cytosol and once dephosphorylated, only translocates to the nucleus upon T cell receptor (Horsley and Pavlath, 2002) and TLR4 stimulation (Zanoni et al., 2009). Within the nucleus, NFATc2 becomes a member of the nuclear factor of activated $\mathrm{T}$ cells transcription complex (Aliprantis and Glimcher, 2010; Sitara and Aliprantis, 2010). This complex not only plays a central role in inducing gene transcription during the immune response, but has been implicated as a necessary factor in the growth and differentiation of a number of tissues following a physiological insult (Santini et al., 2001). For example, macrophage presentation of NFATc2 may facilitate the migration and subsequent activation of cells such as fibroblasts to stimulate wound healing (Lemaitre et al., 2003; Sitara and Aliprantis, 2010). Not surprisingly, mRNA levels of NFATc2 did not indicate treatment differences as protein expression levels do not always coincide with gene expression (Gry et al., 2009).
Although NFATc2 protein expression was increased due to treatment, there were marginal changes and variation in gene expression due to treatment. It is important to note that measurement of the relative expression patterns of LPS/TLR-mediated immuneregulatory pathways may not be indicative of general immune system stimulation. Indeed, the enhancement of an immune response through this pathway relies on a complex interplay of intermediates whose ability to transduce the signal into a downstream effect may only rely on their various states of phosphorylation and not on relative expression differences (Hoffmann and Baltimore, 2006). Furthermore, the time-course of the immune-molecular events may occur in the first hours of SARA (Cario and Podolsky, 2000). In addition, there was a large variation in gene expression values between animals, which coincides with many studies that note large variation in RE structure (Ellis et al., 2012) and function (Penner et al., 2009) between individual animals. In the future, assessing the expression of genes in immune cell types will be important to facilitate more cell specific outcomes.

\section{CONCLUSION}

A number of studies have been published indicating increases in LPS and the upregulation of acute phase proteins. However, this study was the first to our knowledge to directly characterize the expression of localized immune targets in the RE during the adaptation to an $\mathrm{HC}$ diet. In this experiment, it has been shown that adaptation was mediated by the immune system to a lesser extent than was previously thought based on gene expression profiling of targets involved in the innate immune system. Based on this research study, future research investigating the localized innate immune response of the RE during grain-induced SARA should consider evaluation of the time course of the response of the grain challenge and the specific immune cell types of the RE.

\section{ACKNOWLEDGEMENT}

We would like to thank the staff at the Ponsonby Sheep Research Station, University of Guelph, for their assistance in animal husbandry and in technical matters. Financial support for this study came from the Ontario Ministry of Agriculture, Food and Rural Affairs (OMAFRA) and the Natural Sciences and Engineering Research Council of Canada (NSERC; BWM) and is gratefully appreciated. 


\section{REFERENCES}

Aliprantis, A.O. and L.H. Glimcher, 2010. NFATc1 in inflammatory and musculoskeletal conditions. Adv. Exp. Med. Biol., 658: 69-75. DOI: 10.1007/978-14419-1050-9_8

AlZahal, O., B. Rustomo, N.E. Odongo, T.F. Duffield and B.W. McBride, 2007. Technical note: A system for continuous recording of ruminal $\mathrm{pH}$ in cattle. $\mathrm{J}$. Anim. Sci., 85: 213-217. PMID: 17179558

Calder, P.C., 2008. Polyunsaturated fatty acids, inflammatory processes and inflammatory bowel diseases. Mol. Nutr. Food Res., 52: 885-897. PMID: 18504706

Cario, E. and D.K. Podolsky, 2000. Differential alteration in intestinal epithelial cell expression of Toll-Like Receptor 3 (TLR3) and TLR4 in inflammatory bowel disease. Infect Immun., 68: 7010-7017. PMID: 11083826

Chen, Z.T., S.L. Li, E.Q. Cai, W.L. Wu and J.S. Jin et al., 2003. LPS induces pulmonary intravascular macrophages producing inflammatory mediators via activating NF-kappaB. J. Cell Biochem., 89: 12061214. PMID: 12898518

Ellis, J.L., J. Dijkstra, J. France, A.J. Parsons and G.R. Edwards et al., 2012. Effect of high-sugar grasses on methane emissions simulated using a dynamic model. J. Dairy Sci., 95: 272-285. PMID: 22192207

Goodlad, R.L., 1978. Biological indicators. . . . a discussion of products, techniques and philosophies. Infect Control Rounds, 2: 4-6. PMID: 10306603

Gozho, G.N., D.O. Krause and J.C. Plaizier, 2006. Rumen lipopolysaccharide and inflammation during grain adaptation and subacute ruminal acidosis in steers. J. Dairy Sci., 89: 4404-4413. PMID: 17033028

Gozho, G.N., D.O. Krause and J.C. Plaizier, 2007. Rumen lipopolysaccharide and inflammation during grain adaptation and subacute ruminal acidosis in steers. J. Dairy Sci., 90: 856-866. PMID: 17033028

Gozho, G.N., J.C. Plaizier, D.O. Krause, A.D. Kennedy and K.M. Wittenberg, 2005. Subacute ruminal acidosis induces ruminal lipopolysaccharide endotoxin release and triggers an inflammatory response. J. Dairy Sci., 88: 1399-1403. PMID: 15778308

Gry, M., R. Rimini, S. Stromberg, A. Asplund and F. Ponten et al., 2009. Correlations between RNA and protein expression profiles in 23 human cell lines. BMC Genomics, 10: 365-365. DOI: 10.1186/14712164-10-365
Hoffmann, A. and D. Baltimore, 2006. Circuitry of nuclear factor kappaB signaling. Immunol. Rev., 210: 171-186. PMID: 16623771

Horsley, V. and G.K. Pavlath, 2002. NFAT: Ubiquitous regulator of cell differentiation and adaptation. J. Cell Biol., 156: 771-774. DOI: 10.1083/jcb.200111073

Khafipour, E., D.O. Krause and J.C. Plaizier, 2009a. Alfalfa pellet-induced subacute ruminal acidosis in dairy cows increases bacterial endotoxin in the rumen without causing inflammation. J. Dairy Sci., 92: 1712-1724. PMID: 19307653

Khafipour, E., D.O. Krause and J.C. Plaizier, 2009b. A grain-based subacute ruminal acidosis challenge causes translocation of lipopolysaccharide and triggers inflammation. J. Dairy Sci., 92: 1060-1070. PMID: 19233799

Kleen, J.L., G.A. Hooijer, J. Rehage and J.P. Noordhuizen, 2003. Subacute Ruminal Acidosis (SARA): A review. J. Vet. Med. A Physiol. Pathol. Clin. Med., 50: 406-414. PMID: 14633219

Lemaitre, R.N., I.B. King, D. Mozaffarian, L.H. Kuller and R.P. Tracy et al., 2003. n-3 Polyunsaturated fatty acids, fatal ischemic heart disease and nonfatal myocardial infarction in older adults: The cardiovascular health study. Am. J. Clin. Nutr., 77: 319-325. PMID: 12540389

Li, S., E. Khafipour, D.O. Krause, A. Kroeker and J.C. Rodriguez-Lecompte et al., 2012. Effects of subacute ruminal acidosis challenges on fermentation and endotoxins in the rumen and hindgut of dairy cows. J. Dairy Sci., 95: 294-303. PMID: 22192209

Maitra, U., S. Davis, C.M. Reilly and L. Li, 2009. Differential regulation of Foxp3 and IL-17 expression in CD4 $\mathrm{T}$ helper cells by IRAK-1. J. Immunol., 182: 5763-5769. PMID: 19380824

Motoi, Y., T. Oohashi, H. Hirose, M. Hiramatsu and S. Miyazaki et al., 1993. Turbidimetric-kinetic assay of endotoxin in rumen fluid or serum of cattle fed rations containing various levels of rolled barley. J. Vet. Med. Sci., 55: 19-25. PMID: 8461422

Muta, T. and K. Takeshige, 2001. Essential roles of CD14 and lipopolysaccharide-binding protein for activation of Toll-Like Receptor (TLR)2 as well as TLR4 Reconstitution of TLR2- and TLR4-activation by distinguishable ligands in LPS preparations. Eur. J. Biochem., 268: 4580-4589. PMID: 11502220 
Nagaraja, T.G. and E.C. Titgemeyer, 2007. Ruminal acidosis in beef cattle: The current microbiological and nutritional outlook. J. Dairy Sci., PMID: 17517750

Olfert, E.D., B.M. Cross and A.A. McWilliam, 1993. Guide to the Care and Use of Experimental Animals. 2nd Edn., Canadian Council on Animal Care, Canada, ISBN-10: 0919087183, pp: 212.

Penner, G.B., M. Taniguchi, L.L. Guan, K.A. Beauchemin and M. Oba, 2009. Effect of dietary forage to concentrate ratio on volatile fatty acid absorption and the expression of genes related to volatile fatty acid absorption and metabolism in ruminal tissue. J. Dairy Sci., 92: 2767-2781. PMID: 19448011

Penner, G.B., M.A. Steele, J.R. Aschenbach and B.W. McBride, 2011. Ruminant nutrition symposium: Molecular adaptation of ruminal epithelia to highly fermentable diets. J. Anim. Sci., 89: 1108-1119. PMID: 20971890

Pfaffl, M.W., A. Tichopad, C. Prgomet and T.P. Neuvians, 2004. Determination of stable housekeeping genes, differentially regulated target genes and sample integrity: Bestkeeper--excel-based tool using pair-wise correlations. Biotechnol. Lett., 26: 509-515. PMID: 15127793

Plaizier, J.C., D.O. Krause, G.N. Gozho and B.W. McBride, 2008. Subacute ruminal acidosis in dairy cows: The physiological causes, incidence and consequences. Vet. J., 176: 21-31. PMID: 18329918

Santini, M.P., C. Talora, T. Seki, L. Bolgan and G.P. Dotto, 2001. Cross talk among calcineurin, Sp1/Sp3 and NFAT in control of p21(WAF1/CIP1) expression in keratinocyte differentiation. Proc. Natl. Acad. Sci., USA., 98: 9575-9580. PMID: 11493684

Sitara, D. and A.O. Aliprantis, 2010. Transcriptional regulation of bone and joint remodeling by NFAT. Immunol. Rev., 233: 286-300. PMID: 20193006

Steele, M.A., G. Vandervoort, O. AlZahal, S.E. Hook and J.C. Matthews et al., 2011b. Rumen epithelial adaptation to high-grain diets involves the coordinated regulation of genes involved in cholesterol homeostasis. Physiol. Genomics, 43: 308316. DOI: 10.1152/physiolgenomics.00117.2010

Steele, M.A., J. Croom, M. Kahler, O. AlZahal and S.E. Hook et al., 2011a. Bovine rumen epithelium undergoes rapid structural adaptations during graininduced subacute ruminal acidosis. Am. J. Physiol. Regul. Integr. Comp. Physiol. 300: R1515-R1523. PMID: 21451145
Steele, M.A., L. Dionissopoulos, O. AlZahal, J. Doelman and B.W. McBride, 2012. Rumen epithelial adaptation to ruminal acidosis in lactating cattle involves the coordinated expression of insulin-like growth factor-binding proteins and a cholesterolgenic enzyme. J. Dairy Sci., 95: 318-327. PMID: 22192211

Thibault, R., F. Blachier, B. Darcy-Vrillon, P. De Coppet and A. Bourreille et al., 2010. Butyrate utilization by the colonic mucosa in inflammatory bowel diseases: A transport deficiency. Inflamm. Bowel. Dis., 16: 684-695. PMID: 19774643

Wang, Q., Y. Zhou, L.N. Jackson, S.M. Johnson and C.W. Chow et al., 2011. Nuclear Factor of Activated $\mathrm{T}$ cells (NFAT) signaling regulates PTEN expression and intestinal cell differentiation. Mol. Biol. Cell, 22: 412-420. PMID: 21148296

Xue, Y., S.F. Liao, K.W. Son, S.L. Greenwood and B.W. McBride et al., 2010. Metabolic acidosis in sheep alters expression of renal and skeletal muscle amino acid enzymes and transporters. J. Anim. Sci., 88: 707-717. PMID: 19820050

Zanoni, I., R. Ostuni, G. Capuano, M. Collini and M. Caccia et al., 2009. CD14 regulates the dendritic cell life cycle after LPS exposure through NFAT activation. Nature, 460: 264-268. PMID: 19525933

Zebeli, Q. and B.N. Ametaj, 2009. Relationships between rumen lipopolysaccharide and mediators of inflammatory response with milk fat production and efficiency in dairy cows. J. Dairy Sci., 92: 38003809. PMID: 19620662 